\title{
The Review and Proposals of Wood-concrete Composite Beams
}

\author{
LI LI $^{1, a}$,XIE Wenhui ${ }^{1, b}$, ZHOU Xianlin ${ }^{1, c}$ \\ (1.Central South University of Forestry and Technology,School of civil engineering and \\ mechanics, Changsha Hunan 410004 China) \\ a779377702@qq.com,b350780321@qq.com,'565349006@qq.com
}

\begin{abstract}
Keywords: wood;concrete;composite beams
Abstract: The wood-concrete composite beams consist of the wooden beams and concrete slabs by using shear connectors together into a whole load.With the development of society and economy as well as the accumulation of experience in scientific research,people have a further understanding and mastering about the structure performance and application of wood-concrete composite beams. This paper will detailedly introduce the research status concerning wood-concrete composite beams at home and abroad, and discuss the application and development of that composite structure.
\end{abstract}

\section{Introduction}

Concrete and steel are high energy consuming and high polluting industrial products, which need to consume a large amount of energy, discharge lot of waste gas, waste water and waste residue, and even affect the global ecological environment. Sustainable development has become a major theme of the international community, in which reflecting the green, energy saving, environmental protection, low carbon is the inevitable choice. Therefore, developing new environmentally friendly building materials, and gradually reducing or even replacing the traditional building materials used in steel and concrete, has become a new challenge in the field of civil engineering in twenty-first century. At present,it is not mature in foreign countries about the research and application of the wood-concrete composite structure, and the domestic research is almost blank.

\section{Research of Timber-concrete Composite Beams in Foreign Countries}

Design and Calculation

In the 70 's of last century, Gurfinkel, Stalnaker and Harrist ${ }^{[1]}$ suggested use the transformed $\mathrm{s}$ ection method to carry on the design of wood-concrete compositebeams as the same method of designing the steel-concrete composite beams.Ceccotti ${ }^{[2]}$ proposed adopt the European Cod e 5 annex $\mathrm{B}$ design formula for the design of part of the shear connection of wood-concret e composite beam,the fo-rmula provides a basis for the design of composite beams.

In 1995, Gutkowski ${ }^{[3]}$ et al proposed a formula to calculate the efficiency of composite beams in the United States of America, University of Colorado.Test results showed that slotted composite beams can effectively resist the interface shear, reduce slippage between the wooden and concrete, improve the combination of the load-carrying capacity of the beams. The bearing capacity of that composite beams is 2.5 to 3 times as large as other beams' which use common nails as shear connectors. The combination efficiency of slotted composite beams is $54.9 \%$ 77.0\%, while the average combination efficiency is $67.2 \%$.

D.Yeoh,M.Fragiacomo,M.D.Franceschi ${ }^{[4]}$ et al. proposed in the wood concrete composite beam design need to pay attention to the follow two things: (1) in the design we can use conversion 
section method; (2)we need to consider two issues: combination beam composite effect and combinations of materials of the time dependent properties.

Experiment

From 1938 to 1942 , Richart and Williams ${ }^{[5]}$ et al.performed the experimental study on the wood concrete composite beam. They studied the triangle plate supplemented with long nails connected with mechanical performance,in which the bearing capacity is the highest, and beam slip and deflection are minimal.

M.Fragiacomo ${ }^{[6]}$ studied the long-term performance of glued laminated wood concrete composite beams. At that time, the finite element model is used to extend the test process to the service life of the structure (50 years).

In 1990,Ceccotti,A.,Fragiacomo, a M.and GiUX U'Y. ${ }^{[7]}$ for a span of $6 \mathrm{~m}$ of glued laminated timber - concrete composite beams under the open sky in the period 5 years of long-term loading test, then to the destructive testing. Finally, in the destruction of the test pieces of the ends of the cut off two slices of adjacent segment girder do push out test, push out test show that the combined beam failure and not shear connectors caused.

In 1992, Ceccotti ${ }^{[8]}$ et al,studied the effect on midspan deflection, beam end interface slip and wood moisture contentof the composite beams with the climate changes in the indoor and normal loads in long term.It was found that the change in stiffness and strength concrete composite beam is not large, so the long-term load and creep on wood-concrete composite beam bearing capacity is not significant.

In 1995, Amadio ${ }^{[9]}$ et al.found that the deformation of the composite beam will increase when the temperature is low through experimental study of wood concrete composite beamson the outdoor.

Mario,Van Deer,Linden ${ }^{[10]}$ have carried out bending test of three kinds of connection types of glued wood concrete composite beams.

Boo Said,E.,Jullien,J.-F and Ceccotti,A. ${ }^{[11]}$ used ABAQUS to establish the three-dimensional finite element model to study long-term performance of glued laminated timber concrete composite structure under the different environment (temperature, humidity) .In their numerical analysis, it is validated the regarding use of full bridge bending test of Eurocode 5 design method and finite element method the accuracy.

In 2006,Richard Persaud ${ }^{[12]}$ conducted a research about wood-concrete composite beam with screw connector which is 7.5 meter span.He used compression plate as a permanent template in his test.

Clouston,P.,bathon,L.A.and Schreyer,A. ${ }^{[13]}$ developed a new laminated wood concrete composite structure, in which the continuous punching steel plate net is partially cemented in glued laminated timber and remaining part of the steel slab is buried in the concrete slab.Fragiacomo,M.and A. ${ }^{[14]}$, established the finite element model of glued laminated wood-concrete composite beams under long-term load.in which the connector was simulated by a continuous spring system.

Leander,A.Graf, Bathon, Markus ${ }^{[15]}$ performed a shear experiment and bending experiment with the continuous steel wire mesh as a connector of wood concrete composite structure, in order to understand the performance of the structure under the limit load.

Applyment

Wood-concrete composite beam was first born during World War II.Due to the scarcity of steel, people used the wood to replace a portion of reinforced concrete. 
Wood-concrete composite beams were usuall used in the form of work for the repair and reinforcement of new buildings, and ancient architecture.

From the 1960 s to the 1990 s, Postulka, Natterer ${ }^{[16 \sim 17]}$ used wood-concrete composite beam theory and technology of practical to repair and renovation of the floor which can reduce the total cost costs.

Another important application of wood-concrete composite beams is the bridge deck system. In 2004, Gutkowski ${ }^{[18]}$ et al. conducted a study on a large span laminated composite beam, which can be considered as a pioneer in the study of the future of wood concrete bridge deck systems.

Jorge Luis Nuns de Goes Carlit, Call Junior ${ }^{[19]}$ built a log-concrete composite beam bridge, connecting pieces of two X-shaped galvanized steel, each long 500mm, with epoxy resin glue 45 degrees glued in the wood.

\section{Research of Wood-concrete Composite Beams in China}

Over the past few decades, due to the scarcity of the resources of our country forestry, the Chinese government has taken measures to limit fell so that the development of wood structure in China has also come to a standstill. We missed the development period. From the structure of solid wood,structure of glued laminated timber,composite wood structure until updated type of wood materials, the concept of wood structure has been no longer the traditional one.In certain forms of architectures the timber materials has been able to replace steel.

Although the development of technology of wood structure is more and more mature, it is still in its infancy stage in respect of the wood-concrete composite structure development in China.Well,in recent years, Nanjing University of Technology has started to study wood-concrete composite beams.

In 2010, Peng Hongyi from Nanjing University of Technology carried out test ${ }^{[20]}$ of 4 timber-concrete composite beams,comprehensively considering the influences on the whole loaded property of the simply supported timber-concrete composite beams with different degree and arrangement of shear connector.

In 2011, Chen Yuandong conducted a test ${ }^{[21]}$ of engineered wood-concrete beams and 1 piece of engineering wood beam. The results showed that compared with the engineering wooden beams the bearing force of the composite beam is greatly improved, and deflection decreases. He deduced the calculation formula for engineering timber-concrete composite beam stiffness, deflection and flexural capacity.

\section{Existing Problems in the Study of Wood-concrete Composite Beams}

At present, domestic and foreign study of wood concrete composite beams is mainly concentrated in the push test of shear connector,destruction test of combination beam,long-term loaded effects of wood beam,the influence on flexural capacity of wood-concrete composite beams becuase of the change of temperature and humidity. In previous studies, the results were lesser about the degree of shear connection and the arrangement of shear connector on the wood-concrete composite beams. At home and abroad,almost no one has studied the rigidity of wood-concrete composite girder bridge and problems about transverse connection. In the study of wood concrete composite beams, the foreign theoretical research is not perfect, but the domestic is in the initial stage, which has influenced its application and development. 


\section{Proposals}

The ultimate goal of scientific research is the services of production of the country. The study of timber concrete composite beams is conducive to the increase of bridge structure and to improve the structure performance of the bridge type building materials, etc.. In view of the domestic and foreign research status of wood-concrete beams, we can enhance the research work as follows:

(1)To investigate the wood and concrete composite girder bridge joint stress mechanism;

(2)To study the wood-concrete composite beam stress performance with different degree o $\mathrm{f}$ shear connection and different types of shear connectors;

(3)Study on the influence of the transverse connection setting mode and section size on the overall stiffness of the composite beam bridge;

(4)Research and develop in line with the actual development of China wood-concrete composite beams using norms or standards for its quality control.

\section{Acknowledgements}

This work was financially supported by The National Natural Science Foundation ( 51478485 .

\section{References}

[1] Giuriani E,Frangipane A.Wood-to-concrete composite section for stiffening of ancient wooden beam floors[R].University of Brescia Technical Report 1991; 14:1-11.

[2] Capretti S,Ceccotti A,DelSenno M \& Lauriola M.On the experimental determinatio

-n of strength and deformation characteristics of timber-concrete composite joints[C].Proceedings of the 5th World Conference on Timber Engineering,Montreux,

17-20 August1 998:774-775.

[3] Gutkowski RM,Brown 14,Shigidi A,Natterer J.Investigation of notched composite wood-concre te connections[J].Journal of Structural Engineering,ASCE, Rest on, Virginia2004;130(10):1553-61.

[4] David Yeoh, Massimo Fragiacomo, Mary De Frances chi, et al. State of the Art on Timber-Conc rete Composite Structures: Literature Review. Journal of Structural Engineering, 2011, 137(10):1085-1095.

[5] Richart E E.,Williams C.B..University of Illinois Bulletin[J].University of Illinois Bulletin,1943, 40(38):1-62.

[6] M. Fragiacomo ,R. M. Murkowski, J. Bligh, et al. Long-term behavior of wood- concrete composite floor/deck systems with shear key connection detail,ASCE Journal of Structural Engineering.

[7] Cocotte A., Fragiacomo M., and Giordano S. Long- term and collapse tests on a timber-concrete composite beam with glued-in connection. Materials and Structures, Special Volume on Timber.

[8] FragiaeomoM.Long-term behaviour of timber--concrete composite beams[C]. Proceedings of the 3rd PhD Symposium in Civil Engineering,Vienna,2000:1: 525-535.74.

[9] Ahmadi,B.H.,Saka,M.P.Behavior of Composite Timber-Concrete Floors[J]. Journa

-1 of Structural Engineering.1993,119(10):3111·3130. 
[10]Mario van deer Linden. Timber-concrete composite beams. Hreon,1999, Vol.44.

No.3215-239.

[11] Boo Sad ie., Julia n, J.-F., and Cocotte, A. Long term modeling of timber-concrete composite structures in variable climates. Proc., The 8th World Conference on Timber Engineering, WCTE 2004, Lahti, F inland, 2004,Vol. 2:143-148.

[12] Persaud R.,Symons D..Design and testing of a composite timber and concrete floor system[J].T he Structural Engineer,2005,84(4):22 36.

[13]Clouston P., BathronL.A., Schreyer A.Shear and bending performance of a novel wood-concret e composite system[J].Journal of Structural Engineering,2005,131(9): 1404-1412.

[14] Fragiacomo M., Cocotte A. Long-term behavior of timber-concrete composite be -ams.I:Finite element modeling and validation. Journal of Structural Engineering,2006, 132(1):13-22.

[15] Bathon,Leander A.,Graf,Markus. A continuous wood-concrete-composite system.

[16] Postulka,J..Holz-Beton-Verbunddecken.36 Jahre Erfahrung,Bautecknic, 1983:74.

[17] Natterer,J.,Hamm,J.and Favre,E.Composite wood-concrete floors for multi-story buildings[C].

International Wood Engineering Conference,1996,3,431-435.

[18] Gutkowski R..Load tests of large wood-concrete beams[Dissertation].Colorado State:Colorado State University,2004.

[19] Jorge Luis Nuns de Goes, Carlit Call Junior. Field Load Test Behavior of Compo

-site Log-Concrete Bridge-P01. Proceedings of the 51st International Convention of Society of Wood Science and Technology November 10-12, 2008 Concepción, CHILE.

[20] Peng Hongyi.Experimental study on wood-concrete composite beams[D].Nanjin-g:Nanjing University of Technology,2010.

[21] Chen Yuandong.Experimental study on engineered wood -concrete composite beams[D].Nanji ng:Nanjing University of Technology,2011. 